УДК 338.48

\title{
ОЦІНКА РІВНЯ РОЗВИТКУ ТУРИЗМУ МЕТОДАМИ КВАЛІМЕТРІї
}

\section{EVALUATION OF THE LEVEL OF TOURISM DEVELOPMENT BY QUALIMETRY METHODS}

\author{
Івченко Любов Олександрівна \\ кандидат фрізико-математичних наук, доцент, \\ Національний університет харчових технологій \\ ORCID: https://orcid.org/0000-0003-4937-1112 \\ Погуда Наталія Вікторівна \\ кандидат економічних наук, доцент, \\ Харківський національний економічний університет імені Семена Кузнеця \\ ORCID: https://orcid.org/0000-0002-8926-9350 \\ Вовк Катерина Михайлівна \\ доктор фрілософрії, \\ Харківський національний економічний університет імені Семена Кузнеця \\ ORCID: https://orcid.org/0000-0002-7113-1839 \\ Ivchenko Liubov \\ National University of Food Technologies \\ Pohuda Nataliia, Vovk Kateryna \\ Simon Kuznets Kharkiv National University of Economics
}

\begin{abstract}
Стаття присвячена питанням оцінки та порівняння рівня розвитку туризму для ряду європейських країн. Задля узагальнюючої оцінки рівня розвитку туризму пропонується використання комплексного показника, що розраховувався методами кваліметрії. Проведено порівняльний аналіз рівня розвитку туризму в 22 країнах Європейського регіону. Дослідження динаміки комплексного показника дозволило виявити тренди та оцінити швидкість зміни цього показника для визначених країн. Результати дослідження показали, що використання двох підходів до розрахунку комплексного показника (на основі абсолютних значень первинних індикаторів та їх питомих значень на душу населення) дозволяє не тільки порівняти рівень розвитку туризму різних країн, а й оцінити потенціал використання людських ресурсів задля розвитку туризму в країні.

Ключові слова: туризм, рівень розвитку туризму, ключові індикатори туризму, кваліметрія, комплексний показник, динамічний ряд.
\end{abstract}

Статья посвящена вопросам оценки и сравнения уровня развития туризма для ряда европейских стран. Для обобщающей оценки уровня развития туризма предлагается использование комплексного показателя, который рассчитывался методами квалиметрии. Проведен сравнительный анализ уровня развития туризма в 22 странах Европейского региона. Исследование динамики комплексного показателя позволило выявить тренды и оценить скорость изменения этого показателя для определенных стран. Результаты исследования показали, что использование двух подходов к расчету комплексного показателя (на основе абсолютных значений первичных индикаторов и их удельных значений на душу населения) позволяет не только сравнить уровень развития туризма разных стран, но и оценить потенциал использования человеческих ресурсов для развития туризма в стране.

Ключевые слова: туризм, уровень развития туризма, ключевые индикаторы туризма, квалиметрия, комплексный показатель, динамический ряд.

The article deals with estimation and comparing the level of tourism development in certain European countries. It is suggested to apply a composite index of the tourism development level in order to provide an overall assessment of the tourism development level. The work emphasises the assessment of perspectives in tourism development from the standpoint of using the country human resources in tourist activity. The comparative analysis has been done, concerning the tourism development in 22 countries of the European region, whose citizens, on the one hand, can be involved 
in travelling to Ukraine, on the other hand, whose experience can be applied in development of inbound and domestic tourism of Ukraine. Within the current research, six key parameters of tourism development were determined with the help of an expert method: direct input into GDP from tourist activity, the quantity of the world arrivals, tourist expenditure in the country itself, interior tourist consumption, inbound tourism and expenses of international tourists within the country. The generalised index was calculated by the method of qualimetry in two ways. In the first case, to determine the composite index, absolute values of single indicators were chosen, in the second case - their specific values in relation to the country population (re-calculated per head of the population). In both cases, the average values for sampling from 22 countries were chosen as basic indices. The authors applied the differentiated method of assessment to compare single indicators of quality to basic indices. The subjective method was used to calculate the generalised composite index. The research into dynamics of the composite index of tourism development allowed revealing the trends and estimate the time rate of this index for specific European countries. The results of the study showed that application of two approaches for calculating the composite index (on the basis of absolute meanings of primary indicators and their specific value per head of the population) allowed not only comparing the level of tourism development in different countries, but also assess the potential of human resources for tourism development in the country.

Keywords: tourism, level of tourism development, key indicators of tourism, qualimetry, complex indicator, time series.

Постановка проблеми. Обговорення можливостей використання наявних ресурсів, природно-ресурсного або економічного потенціалу - лейтмотив, який достатньо часто зустрічається в науковій літературі під час аналізу певних проблем. Труднощі, які виникли в туристичній сорері протягом останніх двох років, особливо гостро порушують питання щодо використання вітчизняного туристичного потенціалу, який має значні резерви та може стати рушієм у покращенні ситуації. 3 іншого боку, сучасні проблеми мають загальносвітові масштаби, а приклади високого рівня розвитку туризму, зокрема, в країнах європейського регіону в «до карантинний» період чисельні. Проблемі розвитку туристичного потенціалу передує задача його оцінки, яка сама по собі $€$ складною і неоднозначною.

3 іншого боку, оцінка поточного стану розвитку туризму на певній території також $€$ комплексною задачею з точки зору урахування фракторів, які його характеризують, та внеску кожного з показників в загальну оцінку. Додатковий аналіз динамічних рядів характеристик рівня розвитку туризму в країнах надає можливість прогнозування та виявлення причин або поштовхів до позитивної чи негативної динаміки. Корисним здається порівняння даних щодо стану та розвитку туризму в різних європейських регіонах, що дозволить визначити спільні риси, узагальнити і спроектувати позитивний досвід на український ґрунт.

Окрема увага в роботі приділяється співвідношенню між рівнем розвитку туризму країни і кількістю її населення. Обговорюються збіги і відмінності результатів, отриманих на основі абсолютних значень вихідних індикаторів рівня розвитку туризму і їх аналогів, розрахованих на душу населення країни.

Аналіз останніх досліджень і публікацій. У більшості наукових джерел рівень розви- тку туризму пов'язаний з туристичним потенціалом, при чому увага приділяється саме туристично-рекреаційному підходу $[1 ; 2 ; 3]$. Заслуговує на увагу підхід Марценюк Л.В. [4] у оцінці розвитку туризму на основі використання природних ресурсів, де автор визначає, що одночасна ємність природних ресурсів України, з урахуванням максимально можливого навантаження становить 50 млн. чоловік, однак, порівнюючи з реальними даними, рівень використання внутрішніх туристичнорекреаційних ресурсів варіюється в межах 8\%. Святохо Н.В. окрім детального розгляду складових туристичного потенціалу території значну увагу зосереджує на можливості отримання соціально-економічного ефекту від розвитку туризму, де велика роль приділена кадровому потенціалу території [5].

Спираючись на дослідження Михайліченко Г.І. [6] для оцінки туристичного потенціалу території частіше прийнято використовувати показники туристичного балансу. Автор дослідження аргументовано доводить, що зазначений метод оцінки $є$ дуже розповсюдженим, i, у той же час, $є$ недосконалим. Тому розглядається підхід на основі «притягування туристичної маси» до споживання туристичних ресурсів регіону завдяки різним заходам. Використання гравітаційних моделей для оцінки рівня розвитку туризму знайшло відображення у праці Забалдіної Ю.Б. [7], де розглядається, що залежність між обсягами туристичних потоків та регіонами світу прямо пропорційна певній «масі» регіонів і обернено пропорційна «відстані» між ними.

Зокрема, [8] присвячена оцінці поточного стану та розвитку туризму у світі та Україні у динаміці, фракторам розвитку та стримування внутрішнього туризму, дослідженню чутливості розвитку туризму від подій локального та світового масштабу. У праці [9] окрім оцінки 
стану розвитку туризму значну увагу зосереджено на внеску туризму (прямого, непрямого та індуційованого) у ВВП (у зайнятість населення). Варто відмітити, що автор дослідження прослідковує для країн з низьким рівнем доходу більш вищу залежність внутрішнього споживання від ВВП на одиницю населення, ніж у країнах з високим рівнем доходу, і більш інтенсивне відновлення туризму відбувається саме у країнах, що динамічно зростають, у порівнянні з розвинутими країнами.

Виділення невирішених раніше частин загальної проблеми. Незважаючи на значну кількість публікацій, що присвячені аналізу показників туризму та оцінці рівня його розвитку за окремими індикаторами, не до кінця вивченими є питання саме комплексної оцінки рівня розвитку туризму, порівняння динаміки туризму для окремих країн, а також оцінці перспектив розвитку туризму з точки зору використання людських ресурсів країни в туристичній діяльності.

Формулювання цілей статті (постановка завдання). Відповідно метою дослідження $є$ визначення узагальнюючого показника рівня розвитку туризму, що дозволить провести порівняльний аналіз та кількісно оцінити швидкість зміни цього показника для різних країн на основі абсолютних значень фракторів і їх питомих значень на душу населення країни.

Виклад основного матеріалу дослідження. Необхідність активних кроків у бік розвитку українського туризму, про який заявляють фахівці на різних рівнях організації туристичної діяльності, перш за все, потребує оцінки його стану у порівнянні з іншими країнами та отримання кількісних вимірювань динаміки відповідних характеристик. Аналіз статистичних даних щодо рівня розвитку туризму дозволяє сорормулювати основні ідеї, які пропонується перевірити у ході виконання дослідження:

- для оцінки рівня розвитку туризму слід використовувати не окремі статистичні показники щодо туристичної діяльності в країні, а комплексний узагальнюючий показник, який може бути розрахований методами кваліметрії;

- проведення відбору фракторів, які можуть бути включені до розрахунку комплексного показника, передбачається методами кореляційного аналізу;

- з метою проведення порівняльного аналізу рівня розвитку туризму сорормувати вибіркову сукупність з європейських країн - сусідів України, які, з одного боку, користуються попитом у українських туристів, а з іншого - можуть бути конкурентами в наданні туристичних послуг;
- дослідження динаміки комплексного показника дозволить не тільки виявити тренди, але й оцінити швидкість зміни цього показника для різних країн та проаналізувати причини;

- здається доцільним отримання комплексного показника двома способами: 3 використанням абсолютних значень фракторів, що включаються в розрахунок, і їх питомих значень на душу населення країни.

Дійсно, оцінка рівня розвитку туризму в тій чи іншій країні може бути проведена в рамках теорії вимірювання та оцінки якості - кваліметрії. Кваліметрія є однією з трьох основних складових науки про якість. Методами кваліметрії в сучасних умовах вирішуються завдання оцінки якості будь-яких предметів, об'єктів або процесів, зокрема, і в економічній діяльності людей [10]. Кількісні (кваліметричні) методи оцінки в даний час використовуються достатньо широко в самих різних галузях людської життєдіяльності і їх результати можуть бути підставою для прийняття обґрунтованих рішень в управлінні якістю певного продукту. За ідеологією, що пропонує кваліметрія, якщо якість будь-чого визначається рядом індикаторів, її слід оцінювати деяким узагальненим показником - сукупною характеристикою досліджуваного об'єкта. Значення кожного 3 індикаторів порівнюються 3 еталоном, а саме, з певним нормативним або рекомендованим рівнем. Таким чином кваліметричними методами визначається узагальнюючий показник якості продукту, послуги або будьякого іншого об'єкту.

Для визначення номенклатури індикаторів рівня розвитку туризму використовувався експертний метод, який заснований на урахуванні думок фрахівців-експертів в галузі туризму. Використання експертного методу дозволяє не тільки позначити основні індикатори, які повинні бути включені в розрахунок підсумкового показника, але і встановити вагомість (важливість) кожного індикатора в його фрормуванні. Остаточний список показників визначається експертами з урахуванням перевірки узгодженості вибору кожного експерта з загальним складом показників в групі.

Рівень узгодженості експертів визначається показником $\alpha$ і знаходиться за фрормулою:

$$
\alpha_{A}=\frac{m(A)}{m},
$$

де $m(A)$ - число експертів, які включили показник А в групу;

$m$ - загальне число експертів [10].

В якості одиничних, таких, що виражають прості властивості об'єкта (в даному випадку туристичної галузі країни), були взяті статис- 
тичні дані найбільшого світового каталогу відкритих і публічних даних Knoema [11].

Згідно з правилами експертного методу, в роботі розраховувались значення рівня узгодженості для кожного індикатора, зазначеного хоча б одним експертом, залишались ті індикатори, для яких $\alpha(A)>0,5$, вони і були включені в групу для визначення узагальнюючого показника:

- прямий внесок від туристичної діяльності у ВВП (млрд. дол. США);

- кількість світових прибуттів (тис. осіб);

- всього прибутків (тур. витрати всередині країни ), млн.дол. США;

- внутрішнє споживання туризму (млрд. дол.);

- в"їзний туризм (млн. дол.);

- витрати міжнародних туристів всередині країни (млн. дол.).

Безумовно, всі ці показники $\epsilon$ сильно корельованими величинами. Багато в чому і в зв'язку з цією обставиною було вирішено провести оцінку комплексного показника не тільки на основі абсолютних значень вибраних показників, але і з урахуванням їх питомих величин щодо населення країни.

Для розрахунку відносних показників, заснованих на порівнянні одиничних індикаторів з базовими показниками, в якості «еталону» використовувались середні значення для вибірки 322 країн. Залежно від способу порівняння одиничних індикаторів якості 3 базовими показниками розрізняють дисреренційний, комплексний і змішаний методи визначення комплексного показника. В цій роботі використовувався диференційований метод оцінки, коли розраховують рівні одиничних показників властивостей за фрормулами:

$$
K_{i}=\frac{P_{i}}{P_{i}^{\text {базовй }}}
$$

де $P_{i}-$ значення $i$-го одиничного показника якості оцінюваної продукції або послуги,

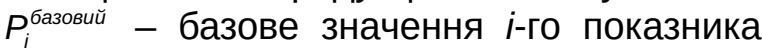
(в цій роботі - середнє за вибіркою).

Наступний етап: визначення значення узагальненого комплексного показника. Використання на цьому етапі об'єктивних методів передбачає наявність між комплексним показником якості продукції і його одиничними показниками функціонального зв'язку. Однак, по-перше, отримати таку фрункціональну залежність достатньо складно, а по-друге, зробити це заважає наявність відчутного кореляційного зв'язку між одиничними показниками. Тому в даній роботі було застосовано суб'єктивний спосіб утворення комплексних показників за принципом середнього арифметичного зваженого. Для розрахунку комплексного показника рівня розвитку туризму країни використовувалась формула:

$$
K=\sum_{i=1}^{n} K_{i}{ }^{*} W_{i}
$$

де $K_{i}-$ відносний одиничний індикатор;

$w_{i}$ - коефріцієнт вагомості $i$-го індикатора;

$n$ - кількість одиничних індикаторів.

Експертною групою із 20 осіб було обрано шість одиничних індикаторів ступеню розвитку туризму в країні. Розподіл показників на рівні задля побудови складного дерева властивостей не здійснювався. Експертним шляхом було встановлено значущість кожного із одиничних індикаторів в загальному показнику розвитку туризму країни. В табл. 1 наведено номенклатуру обраних індикаторів, рівень узгодженості експертів за кожним із них та вагові коесріцієнти кожного із індикаторів у підрахунку загального показника.

Критерії, за якими обирались країни для розрахунку комплексного показника рівня розвитку туризму і подальшого порівняння результатів [10]:

- країни, які розташовані в найближчому європейському регіоні і громадяни яких можуть бути залучені до подорожей в Україну;

- країни, в яких рівень ВВП на душу населення вище вітчизняного показника і чий досвід може бути використаний в розвитку в"їзного та внутрішнього туризму України.

У підсумку було обрано 22 країн, а для більш детального аналізу складено динамічні ряди всіх шести індикаторів за 6 років (2014-2019 рр.). Комплексний (підсумковий) показник розраховувався двома способами:

Перший. В якості одиничних індикаторів в фрормулі (2) вибирались абсолютні значення кожного з шести показників, а в якості базових - їх середнє значення за всіма країнами, що аналізувались.

Другий. В якості одиничних індикаторів використовувались питомі значення кожного із індикаторів відносно загальної чисельності населення країни, тобто їх значення у перерахунку на душу населення. Такий підхід здається доцільним з огляду на те, що надходження від туризму в перерахунку на душу населення країни $€$ більш відчутним індикатором впливу розвитку туризму на рівень життя кожного громадянина.

На рис. 1 представлено результати розрахунку комплексного показника для 22 країн першим способом. Всі дані ранжовані за зменшенням показника і умовно об'єднані в 4 групи: 
Таблиця 1

Дані експертної оцінки одиничних індикаторів розвитку туризму в країні [10]

\begin{tabular}{|c|c|c|c|c|c|c|}
\hline & 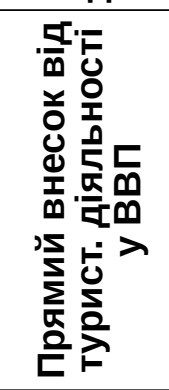 & 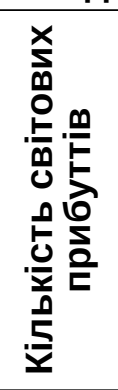 & 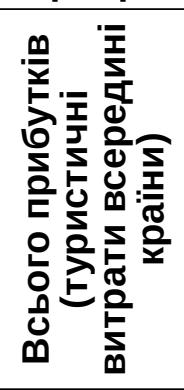 & 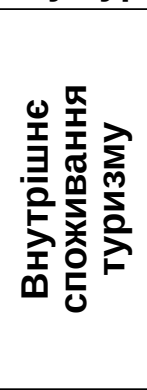 & 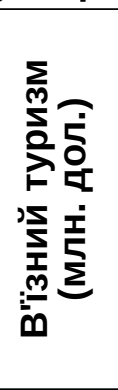 & 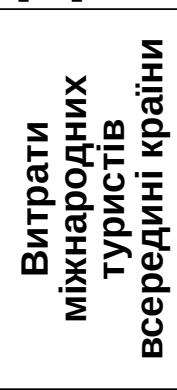 \\
\hline $\begin{array}{l}\text { Рівень узгодженості } \\
\text { експертів } \alpha\end{array}$ & 1,00 & 0,85 & 0,8 & 0,7 & 0,75 & 0,7 \\
\hline Коесріцієнти вагомості $w_{i}$ & 0,25 & 0,2 & 0,2 & 0,1 & 0,15 & 0,1 \\
\hline
\end{tabular}

Перша група - країни, для яких значення комплексного показника розвитку туризму виявилося вище середнього («еталонного») значення.

Друга група - країни, рівень розвитку туризму в яких, за нашими оцінками, знаходиться на рівні середнього (значення комплексного показника близько 1 ).

Третя група - країни з комплексним показником нижче середнього.

Четверта група - найнижчі значення узагальнюючого показника.

До першої групи потрапили країни, які $€$ визнаними лідерами розвитку туризму. Про це свідчать значення всіх 6 одиничних індикаторів, що були об'єднані в комплексному показнику. Україна потрапила в групу з найменшим значенням комплексного показника. Зауважимо, що при цьому не враховувались дані про населення країн.

Аналіз динамічних рядів комплексного показника для кожної 3 досліджуваних країн дозволив визначити швидкість його зміни протягом 2014-2019 рр. На рис. 2 представлено динаміку комплексного показника для країн з першої групи. 3'ясувалось, що для деяких країн з найкращим рівнем розвитку туризму цей показник практично не змінювався протягом досліджу-

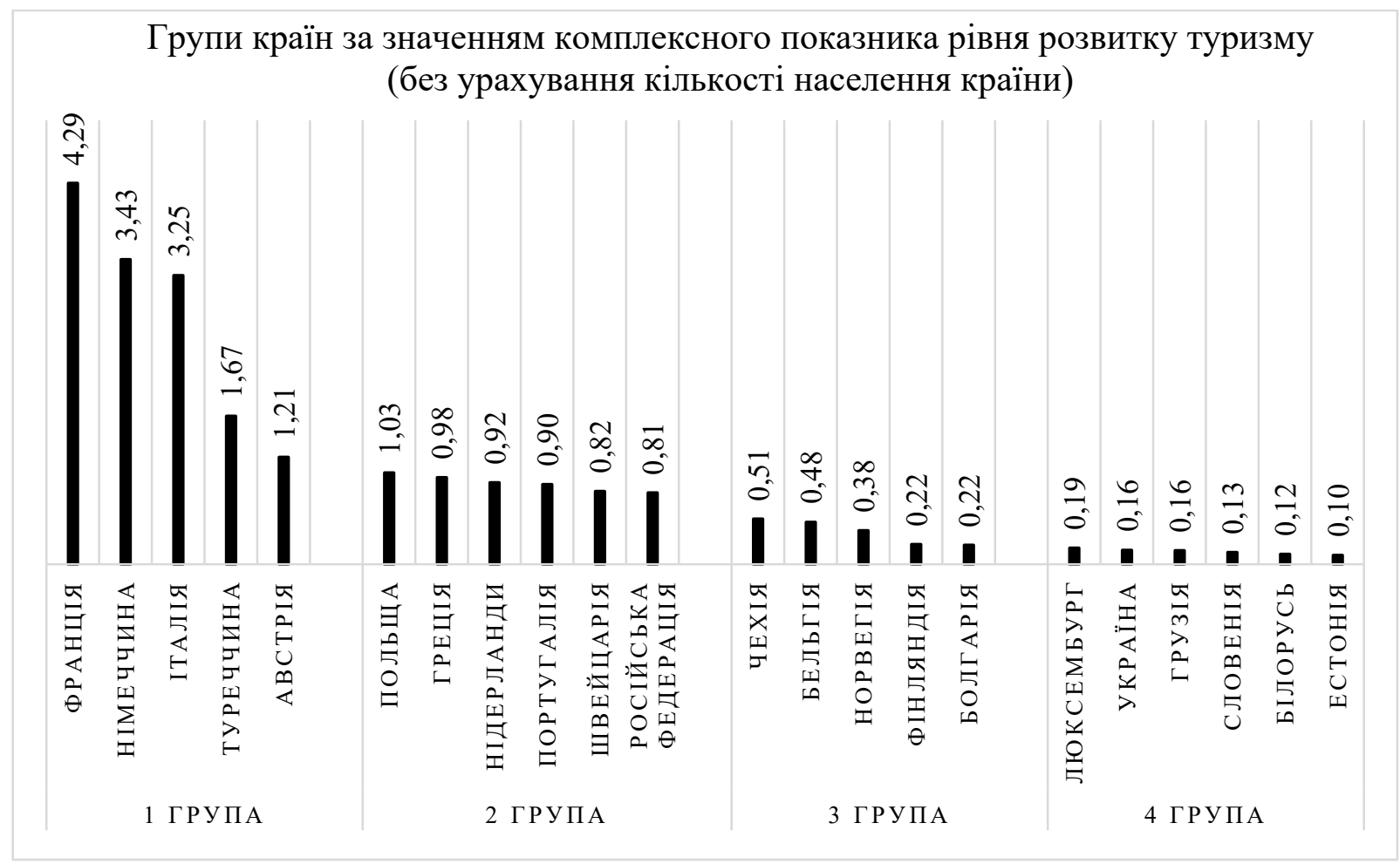

Рис. 1. Результати розрахунку комплексного показника рівня розвитку туризму за абсолютними значеннями одиничних індикаторів 


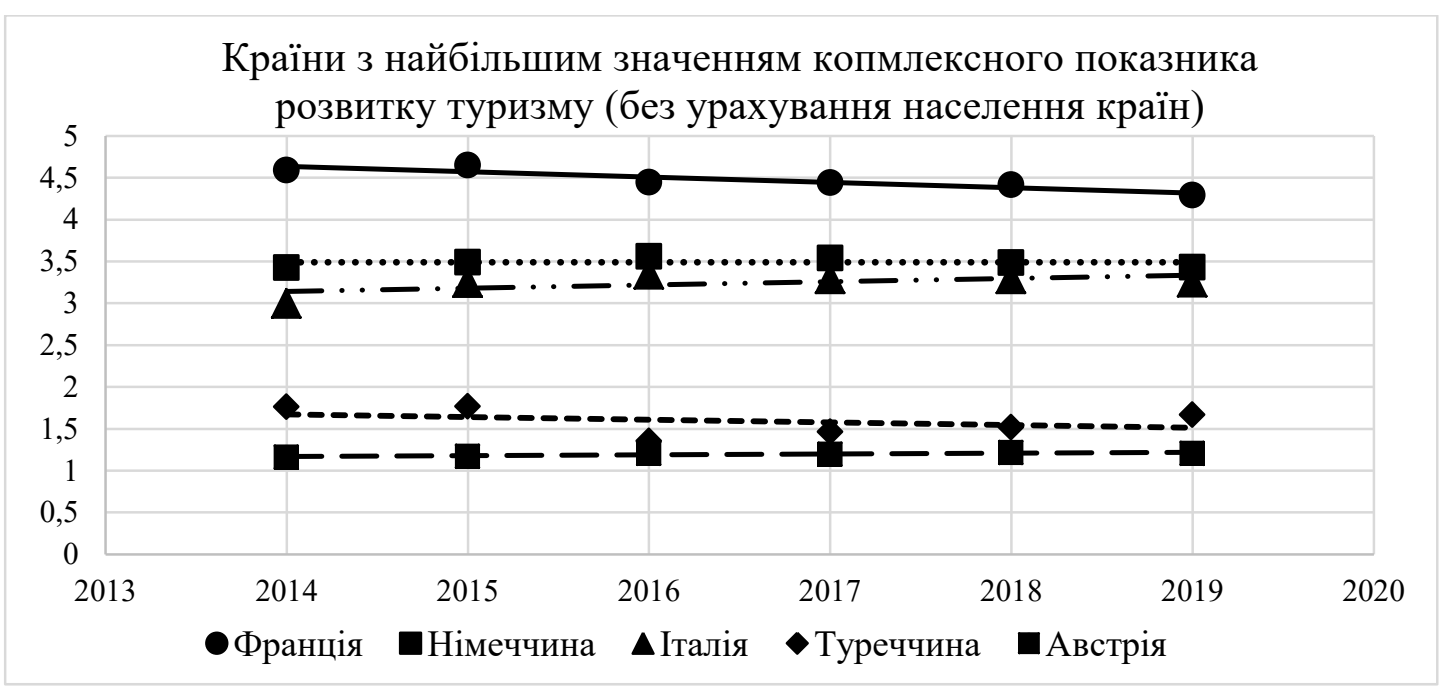

Рис. 2. Динаміка комплексного показника розвитку туризму для країн 1 групи

ваного періоду (коефріцієнт приросту за 6 років для Австрії становить 1,04, для Італії - 1,08, для Німеччини - 1,00), а для деяких членів цієї групи він навіть знизився (коесріцієнт приросту для Туреччини складає 0,95, а для Франції 0,93)

А найбільш динамічний розвиток туризму, за даними комплексного показника протягом 6 років, виявився у наступних країн: Білорусь (коеоріцієнт приросту 1,34), Грузія (1.52), Португалія $(1,31)$, Нідерланди $(1,18)$ (рис. 3). Звертає на себе увагу те, що до різних груп 3 приблизно однаковими значеннями комплексного показника розвитку туризму (рис. 1) потрапили країни з суттєво різним даними щодо кількості населення.

Так, наприклад, в першу групу потрапили Туреччина (близько 83,4 млн. населення) та Австрія (8,9млн. населення). Україна (44.4 млн. населення) разом 3 Люксембургом (біля 0,62 млн. населення) потрапила в останню групу 3 найменшими значеннями комплексного показника розвитку туризму.

У зв'язку з цими спостереженнями було вирішено оцінити та порівняти значення комплексного показника розвитку туризму на основі «питомих» значень одиничних індикато-

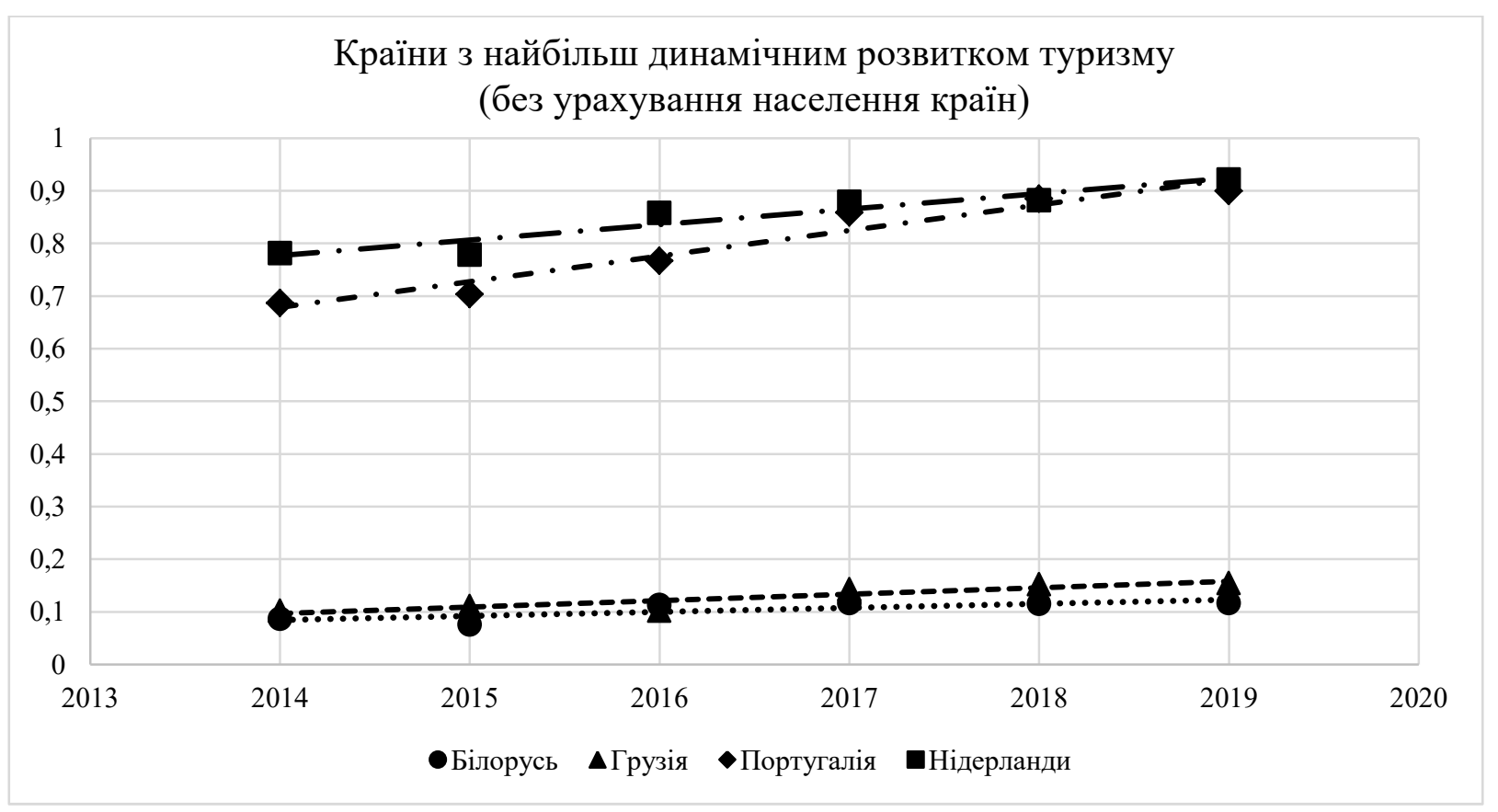

Рис. 3. Країни з найбільш динамічним розвитком туризму за даними динаміки комплексного показника 
рів (табл. 1), а саме, в їх перерахунку на душу населення країни. Розподіл значень комплексного показника i, відповідно, фрормування груп країн, виявилися зовсім іншим (рис. 4).

За рахунок невеликої кількості населення Люксембург отримав найбільшу «питому» узагальнену оцінку рівня розвитку туризму. Тільки Австрія опинилась в першій групі незалежно від способу розрахунку комплексного показника. Україна за оцінкою рівня розвитку туризму на душу населення отримала найменше значення показника: великий потенціал використання людських ресурсів одночасно 3 низькими значеннями одиничних індикаторів. Дійсно, наприклад, дані за кількістю світових прибуттів в Україні і Швейцарії одного порядку (14 млн. і 12 млн. відповідно), але при цьому населення України у 5 разів більше населення Швейцарії (44 млн і 8,5 млн. відповідно).

За показником прямого внеску туризму у зайнятість можна також відмітити, що Україна має один із найнижчих показників (за даними Світового банку у 2019 р.) [12]. Зокрема, в Росії даний показник становив 1,32\%, Україні 1,44\%, Білорусь 1,99\%, Люксембурзі 2,28\%, Франції 4,33\%, Італії 6,41\%, Австрії 6,65\%, Німеччині 7,27\%. Тобто потенціал залучення людського ресурсу для України $є$ величезний, що дозволить покращити не лише зайнятість населення, але й відповідно і розвиток безпосередньо самого туризму в країні.

Притаманна туризму така властивість як мультиплікативність, забезпечує здатність генерувати не лише фрінансові накопичення, але й розвивати суміжні ссрери та забезпечувати населення країни додатковими робочими місцями. За даними Всесвітньої ради подорожей та туризму кожне нове 4 робоче місце протягом останніх 5 років було створено саме туристичній сфрері [13]. Зокрема, за даними ЮНВТО [14] кожні 10 туристів дають роботу 2 працівникам, а кожне додатково створене робоче місце у туристичній сорері створює 4 робочі місця у суміжних сферах.

Враховуючи, що туристична статистика для обраних країн подається за різними методологіями розрахунку туристичних потоків, частину туристів, які увійшли до загального складу туристів складають особи, що перетинають кордони 3 метою працевлаштування. Тому особливо актуальним стає питання зайнятості населення саме в середині країни, у тому числі залученість так званих «заробітчан» 3 метою розвитку внутрішнього туризму. Для цього необхідно, щоб зростав туристичний потік у країні, що в свою чергу, дозволить створювати додаткові робочі місця, розвиватиме не лише туристичну, але й суміжні з нею сфрери.

Безумовно, розподіл за групами є достатньо суб'єктивним, особливо на стику різних груп. Але завдяки саме цим даним можливо оцінити загальний вплив рівня розвитку туризму, надходжень, як від в"їзного, так і внутрішнього туризму, надходжень від споживання туристичних продуктів на рівень добробуту кожного громадянина країни.

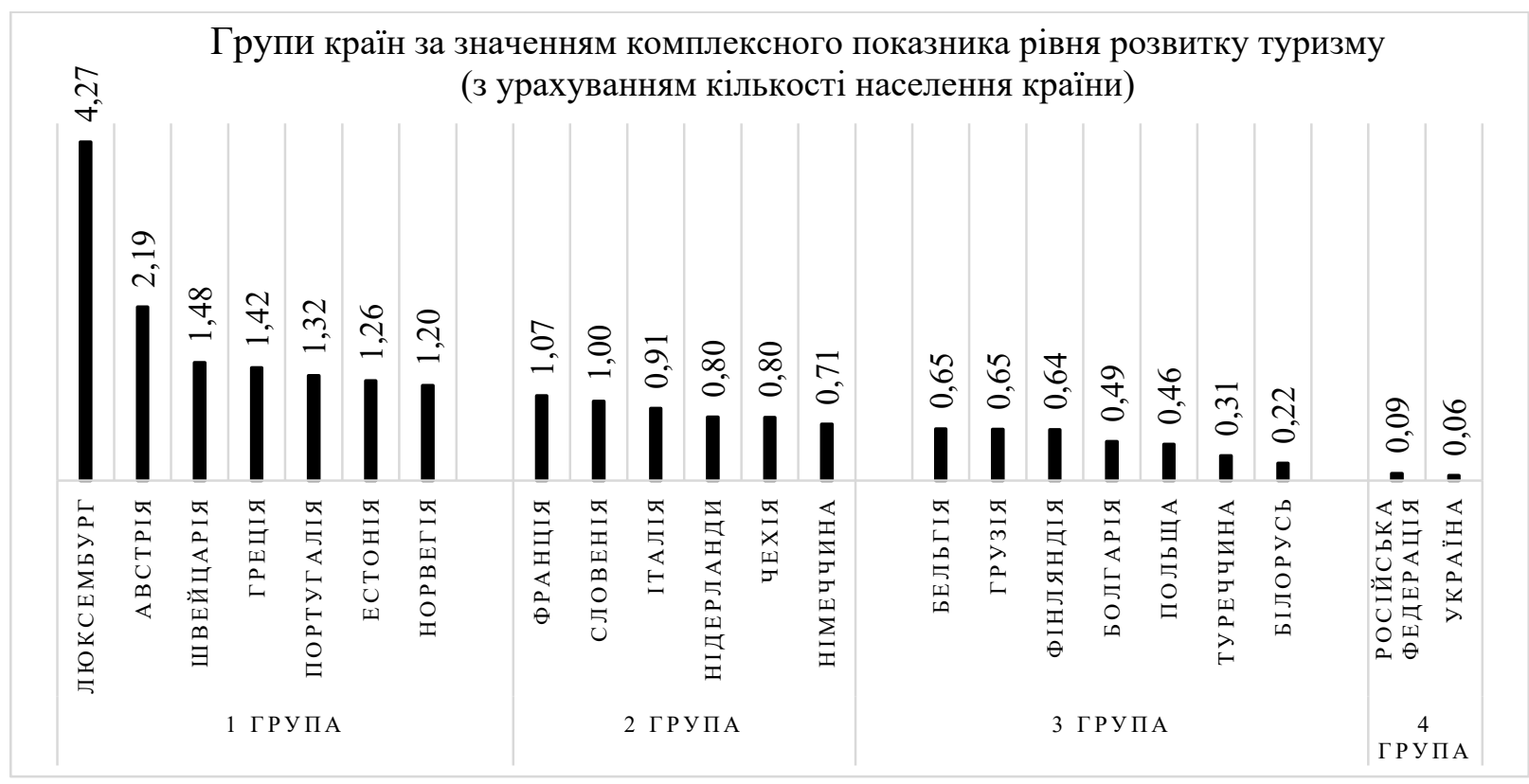

Рис. 4. Результати розрахунку комплексного показника рівня розвитку туризму за «питомими» значеннями одиничних індикаторів 
Країни, що опинились в першій групі на рис. 4 з найбільшими значеннями показника рівня розвитку туризму за «питомими» значеннями одиничних індикаторів, максимально використовують людські ресурси своєї країни. Відповідно, і динаміка комплексного показника в основному має постійний або від'ємний характер. Із 7 країн першої групи тільки Греція та Португалія мають відносний коефіцієнт зростання в період 2014-2019 рр. більший за одиницю (1,12 та 1,37 відповідно) (рис. 5).

Серед 22 країн, що досліджувались, найбільш динамічний розвиток туризму спостерігається для Португалії (коефріцієнт зростання 2019/2014 рр. становить 1,37), Білорусь (коефріцієнт зростання 1,39) та Грузія (коефіцієнт зростання 1,51) (рис. 6).

Отже, результати щодо формування групи країн 3 найбільшою швидкістю розвитку туризму практично повторюються і при використанні обох способів підрахунку комплексного показника.

Країни, які вийшли «динамічними» за обома підходами (абсолютним та питомим) заслуговують на увагу щодо практики впровадження дієвих заходів і для України. Зокрема, найбільш динамічними показниками протягом 2014-2019 рр. були прямий внесок від туристичної діяльності у ВВП, кількість світових прибуттів, туристичні витрати в середині країни та витрати міжнародних туристів в середині країни. Тобто можна зробити висновок про безпо- середній стійкий розвиток туризму у кожній із 3 зазначених країн. Наприклад, досвід розвитку туризму в Грузії може бути використаний і в Україні у частині розвитку туристичної інфрраструктури, регіонального розвитку туризму, лібералізації податкової політики у сорері послуг та популяризації країни у світі. Досвід сусідньої держави Білорусі може бути цікавим у напрямі єдиної і злагодженої політики розвитку туризму, пропозиції турів «вихідного дня» та «святкових днів» для туристів із країн-сусідів, що $є$ дуже популярними і серед вітчизняних туристів, відповідна якість послуг та державна підтримка і безпека. Недосконалість туристичної статистики може навести на думку, що динамічний розвиток туризму обумовлений врахуванням до чисельності туристичних потоків людей, що їдуть не з метою туризму, а на роботу, або ж відвідуванням родичів. Дійсно, таку динаміку узагальнюючого показника для Білорусі забезпечив, в основному, внесок фрактору кількості світових прибуттів (прикордонний туризм без ночівель). Однак показники туристичних витрат як в середині країни, так і витрат міжнародних туристів підтверджують думку, що їх щорічне зростання, як і самої кількості туристів, є результатом ефективного використання туристичного потенціалу. Так, в Грузії витрати міжнародних туристів всередині країни протягом 2014-2019 рр. зросли майже вдвічі, а в Португалії в 1,5 рази. Приклади даних країн показують, що наявність пам'яток

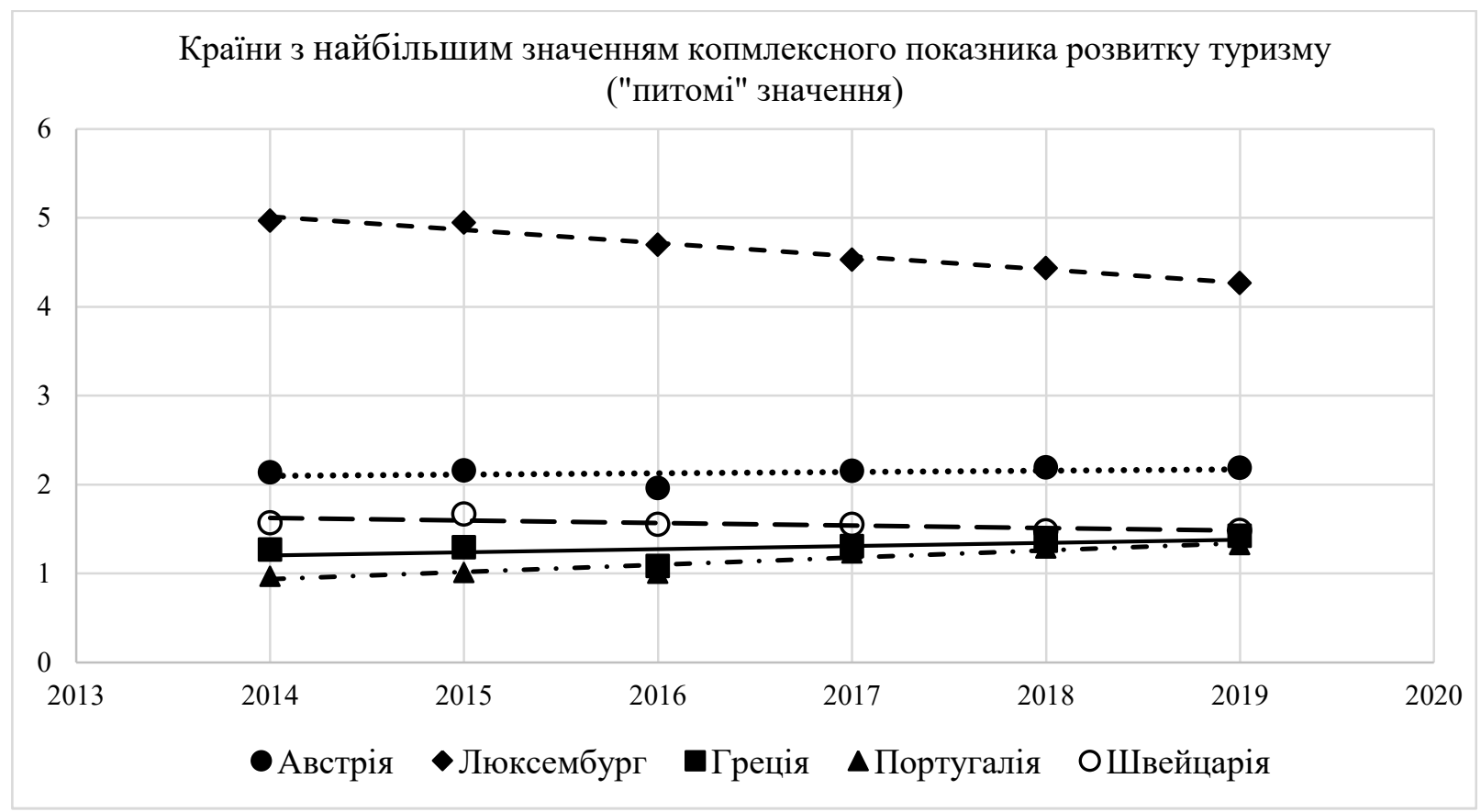

Рис. 5. Динаміка комплексного показника розвитку туризму для країн 1 групи («питомі» значення) 


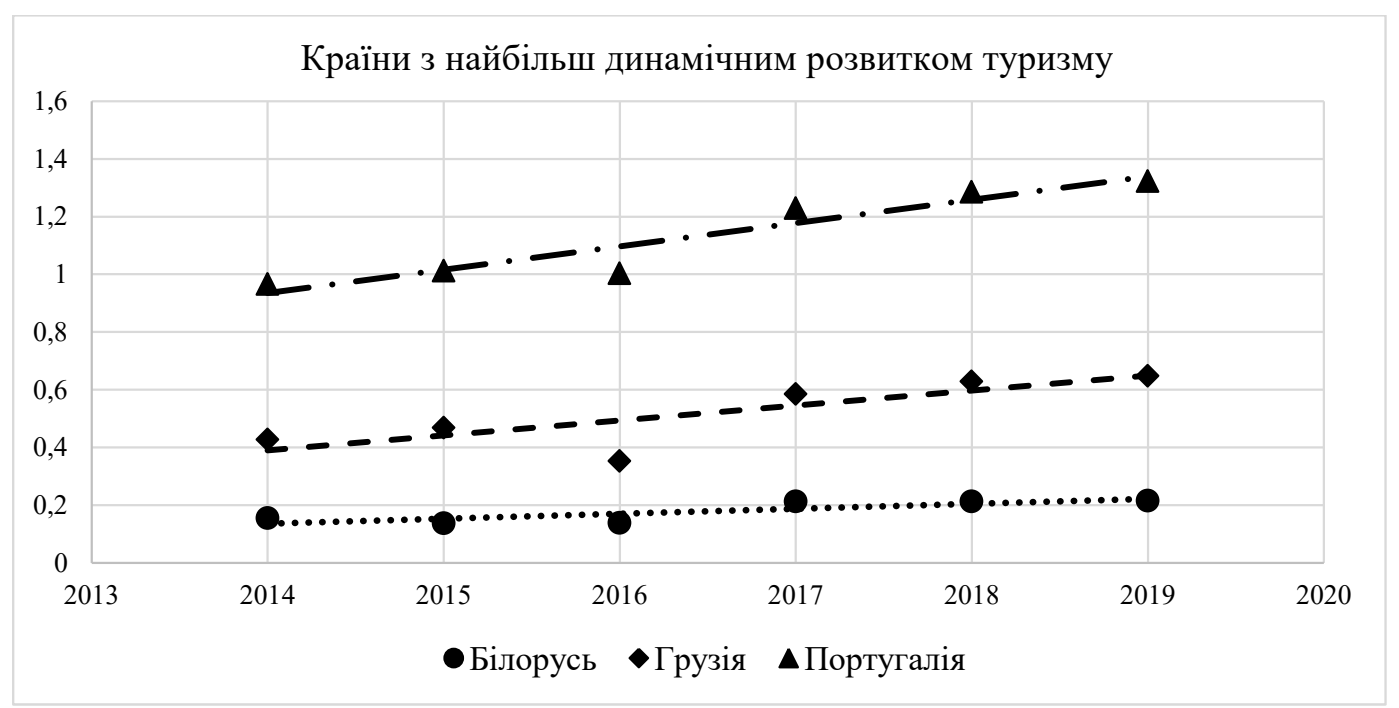

Рис. 6. Країни з найбільш динамічним розвитком туризму за даними динаміки «питомого» комплексного показника

архітектури чи природних ресурсів $є$ базисом для туризму, однак його розвиток можливий за умови ефективної державної політики та стратегічного розвитку ссрери туризму.

Висновки. Оцінка рівня розвитку туризму ряду країн, отримана на основі узагальнюючого показника, дозволила висвітлити наступні моменти:

- для країн з високим рівнем розвитку туризму в основному спостерігається стала, і навіть від'ємна динаміка даного показника, незалежно від способу його розрахунку;

- розрахунок «питомого» узагальнюючого показника рівня розвитку туризму на душу населення країни демонструє можливості використання такої важливої складової потенціалу розвитку туризму, як людські ресурси;

- швидкість позитивної динаміки узагальнюючого показника визначається внеском кожної з його складових, які потребують окремого аналізу (наприклад, в'їзні потоки).

Володіючи значним туристичним потенціалом, який прийнято розглядати як сукупність унікальних природних та антропогенних ресурсів, рекреаційних об'єктів, суттєвою кількістю пам'яток культури і архітектури, певною туристичною інфраструктурою, залишається без розкриття потенціалу та частина, що безпосередньо забезпечує розвиток туризму. Недооцінюючи вплив туризму на рівень економіки країни, поза увагою залишається ряд фракторів, що можуть стимулювати туризм, і відповідно, економічний та соціальний розвиток країни.

Населення та територія - це головні ресурси, що є у кожної країни, які можна використовувати для розвитку туризму, незалежно від наявності рекреаційних можливостей, історичних, культурних або релігійних пам'яток. Відомо, що як світовий розподіл туристичних зон, так і європейський або навіть в кожній країні $€$ достатньо нерівномірним. Отримані в роботі дані продемонстрували не тільки низький рівень розвитку туризму України у порівнянні $з$ іншими європейськими країнами, але й вкрай низький рівень використання людського ресурсу, що може бути залучений до розвитку туристичного потенціалу.

Тому оцінка комплексного показника рівня розвитку туризму у розрахунку на кожного громадянина країни дозволяє оцінити і людський потенціал, який може забезпечити цей розвиток. Крім того, це може бути оцінкою потенційних можливостей країни щодо подальшого розвитку туристичної галузі.

\section{СПИСОК ВИКОРИСТАНИХ ДЖЕРЕЛ:}

1. Руденко В.П., Вацеба В.Я., Соловей Т.В. Природо-ресурсний потенціал природних регіонів України : монографія. Чернівці : Рута, 2001. 268 с.

2. Черчик Л., Коленда Н. Стратегічний потенціал рекреаційної системи регіону: теорія, методологія, оцінка : монограсрія. Луцьк : ЛНТУ, 2008. 224 с.

3. Писаревський І.М., Мелешко К.К. Туристично-рекреаційний потенціал як елемент конкурентоспроможності територій. БізнесІнформ. 2019. № 12. С. 148-154. 
4. Марценюк Л.В. Проблеми та перспективи розвитку туризму в Україні. Економічний вісник. 2015. № 3. С. $76-82$.

5. Святохо Н.В. Сущность и компоненты туристского потенциала территории. Культура народов Причерноморья. 2006. № 88. С. 95-98.

6. Михайліченко Г.І. Туристичний потенціал: методи оцінювання та інноваційний розвиток. Проблеми економіки. 2013. № 1. С. 115-123.

7. Забалдіна Ю.Б., Ліщинський О.Л. Дві адаптивні моделі короткострокового прогнозування туристичних потоків. Стратегія розвитку України (економіка, соціологія, право). 2006. № 1. С. 406-410.

8. Погуда Н.В., Примак Т.Ю., Івченко Л.О. Дослідження чутливості туристичних потоків до впливу світових та локальних фракторів. Вчені записки ТНУ ім. В.І. Вернадського. Серія Економіка і управління. 2020. Tом 31(70). № 2. С. 119-124.

9. Максимюк М.Н. Оценка состояния и перспективы развития индустрии туризма в Украине. Культура народов Причерноморья. 2012. № 235. С. 55-61.

10.Вовк К.М. Управління розвитком подієвого туризму в регіоні : дис. д-ра фрілософрії : 64.055 .015 / ХНЕУ ім. С. Кузнеця. Харків, 2021. 264 с.

11. Світовий атлас даних. Офріційний сайт. Knoema: портал інфографріки. URL: https://bit.ly/3t5AlaU

12. Світовий банк. Офріційний сайт. Внесок туризму. URL: https://bit.ly/2PAqLiw

13. Всесвітня рада подорожей та туризму. Офіційний сайт. Модель витрат та вигод і технічна доповідь. URL: https://bit.ly/3xvPK7G

14. Всесвітня туристична організація. Офріційний сайт. Статистика. URL: https://www.unwto.org/ru/node/116

\section{REFERENCES:}

1. Rudenko, V.P., Vatseba, V.Ya. \& Solovey, T.V. (2001). Pryrodo-resursnyi potentsial pryrodnykh rehioniv Ukrainy [Natural resource potential of natural regions of Ukraine]. Chernivtsi: Ruta. (in Ukrainian)

2. Cherchyk, L. \& Kolenda, N. (2008). Stratehichnyi potentsial rekreatsiinoi systemy rehionu: teoriia, metodolohiia, otsinka [Strategic potential of the recreational system of the region: theory, methodology, evaluation]. Lutsk: LNTU. (in Ukrainian)

3. Pisarevsky, I.M. \& Meleshko, K.K. (2019). Turystychno-rekreatsiinyi potentsial yak element konkurentospromozhnosti terytorii [Tourist and recreational potential as an element of competitiveness of territories]. Biznes/nform [BusinessInform], 12, 148-154. (in Ukrainian)

4. Martsenyuk, L.V. (2015). Problemy ta perspektyvy rozvytku turyzmu v Ukraini [Problems and prospects of tourism development in Ukraine]. Ekonomichnyi visnyk [Economic Bulletin], 3, 76-82. (in Ukrainian)

5. Svyatoho, N.V. (2006). Suschnost i komponentyi turistskogo potentsiala territorii [Essence and components of the tourist potential of the territory]. Kultura narodov Prichernomorya [Culture of the peoples of the Black Sea region], 88, 95-98. (in Russian)

6. Mikhailichenko, G.I. (2013). Turystychnyi potentsial: metody otsiniuvannia ta innovatsiinyi rozvytok [Tourism potential: evaluation methods and innovative development]. Problemy ekonomiky [Problems of the economy], 1, 115-123. (in Ukrainian)

7. Zabaldina, Y.B. \& Lishchinsky, O.L. (2006). Dvi adaptyvni modeli korotkostrokovoho prohnozuvannia turystychnykh potokiv [Two adaptive models of short-term forecasting of tourist flows]. Stratehiia rozvytku Ukrainy (ekonomika, sotsiolohiia, pravo) [Development strategy of Ukraine (economics, sociology, law)], 1, 406-410. (in Ukrainian)

8. Pohuda, N.V., Prymak, T.Yu. \& Ivchenko, L.O. (2020). Doslidzhennia chutlyvosti turystychnykh potokiv do vplyvu svitovykh ta lokalnykh faktoriv [Research of sensitivity of tourist flows to effects of world and local factors]. Vcheni zapysky TNU im. V.I. Vernadskoho. Seriia Ekonomika i upravlinnia [Scientific notes of TNU. V.I. Vernadsky. Series Economics and Management], 31(70), 2, 119-124.

9. Maksimyuk, M.N. (2012). Otsenka sostoyaniya i perspektivyi razvitiya industrii turizma v Ukraine [Assessment of the state and prospects for the development of the tourism industry in Ukraine]. Kultura narodov Prichernomorya [Culture of the peoples of the Black Sea region], 235, 55-61. (in Russian)

10. Vovk, K.M. (2021). Upravlinnia rozvytkom rodiievoho turyzmu v rehioni [Management of the development of rhodium tourism in the region]. PhD thesis, Kharkiv. (in Ukrainian)

11. World data atlas (2021). Knoema: portal of infographics. Available at: https://bit.ly/3t5AlaU

12. World Bank (2021). Direct contribution of tourism. Available at: https://bit.ly/2PAqLiw

13. WTTC (2021). Cost-benefit model and technical report. Available at: https://bit.ly/3xvPK7G

14. UNWTO (2021). Statistics. Available at: https://www.unwto.org/ru/node/116 